\title{
PKM Promoting Virtual Da'wah for Prosperity of the Mosque-based Youth Activities
}

Abu Khaer ${ }^{1}$, Aisyatul Humairo², Isyti Rozanah ${ }^{3}$, Ika Maziyyatus Sholihah4, Viatul Karimah', Moh. Jalaluddin ${ }^{6}$, Muh Dzikri Izzabillah

Universitas Nurul Jadid, Paiton

\{rikoufeliza@gmail.com ${ }^{1,2,3,4,5,6,7}$ \}

\begin{tabular}{|c|c|}
\hline Submission: $19 / 1$ & Published: 31/12/2021 \\
\hline $\begin{array}{l}\text { Keywords: } \\
\text { Virtual Da'wah, } \\
\text { Prospering } \\
\text { Mosque, Youth } \\
\text { Mosque, Social } \\
\text { Media }\end{array}$ & $\begin{array}{l}\text { Abstract. Da'wah cannot be left from the mosque's existence as a } \\
\text { center of worship and scientific development. The transformation of } \\
\text { the use of digital media has penetrated various communication needs, } \\
\text { including a strategy in virtual preaching by utilizing social media. } \\
\text { Da'wah is no longer carried out by groups considered qualified in } \\
\text { religious understanding, but every individual can do this virtual da'wah. } \\
\text { Within the framework of the prosperity of the mosque, the Youth of the } \\
\text { Mosque Baitissalam Paiton, Probolinggo started to use social media to } \\
\text { spread positive religious values. It has not been accompanied by an } \\
\text { awareness of the importance of concepts and strategies that are strong } \\
\text { in the persuasive messages of virtual da'wah, so they need } \\
\text { reinforcements. This method of community service is carried out by } \\
\text { strengthening the concept of virtual da'wah, mosque youth branding, } \\
\text { and audio-visual training to create interesting social media creative } \\
\text { content attention of millennial youth. The results of community service } \\
\text { activities show awareness social media to design a virtual da'wah } \\
\text { strategy through creative social media content andincreased creativity } \\
\text { in determining ideas to spread religious values for teenagers. }\end{array}$ \\
\hline
\end{tabular}

Katakunci:

Dakwah Virtual, Masjid Makmur, Masjid Pemuda, Media Sosial

\begin{abstract}
Abstrak. Dakwah tidak bisa lepas dari keberadaan masjid sebagai pusat ibadah dan pengembangan ilmu pengetahuan. Transformasi penggunaan media digital telah merambah berbagai kebutuhan komunikasi, termasuk strategi dalam berdakwah secara virtual dengan memanfaatkan media sosial. Dakwah tidak lagi dilakukan oleh kelompok yang dianggap mumpuni dalam pemahaman agama, tetapi setiap individu dapat melakukan dakwah maya ini. Dalam rangka memakmurkan masjid, Pemuda Masjid Baitissalam Paiton, Probolinggo mulai memanfaatkan media sosial untuk menyebarkan nilai-nilai positif keagamaan. Belum dibarengi dengan kesadaran akan pentingnya konsep dan strategi yang kuat dalam pesan persuasif dakwah maya, sehingga perlu penguatan. Metode pengabdian masyarakat ini dilakukan dengan penguatan konsep dakwah virtual, branding pemuda masjid, dan pelatihan audio visual untuk membuat konten kreatif media sosial yang menarik perhatian anak muda milenial. Hasil kegiatan pengabdian masyarakat menunjukkan kesadaran media sosial untuk merancang strategi dakwah virtual melalui konten media sosial yang kreatif dan peningkatan kreativitas dalam menentukan ide untuk menyebarkan nilai-nilai agama bagi remaja.
\end{abstract}




\section{Introduction}

Da'wah is a human need in spiritual life and activities, da'wah can be done in various ways, either through lectures, sermons, or writings ( Risdiana \& Ramadhan, 2019 ). However, in today's technological era, da'wah is not enough through conventional means. The era of globalization has implications for the emergence of the information society. The information society finds convenience abundant since entering the internet era. The community is even easier to connect tointeract. They communicate, behave, work, and think as a digital society (digital native) (Supratman, 2018 ). Digital society is becoming an era trend technology that produces various new media platforms. Technology is one of the important things in influencing the nation's next-generation (Resendy, 2018 ).

Da'wah, of course, cannot be left out of the existence of the mosque. The mosque isa holy place that is no stranger to its position for Muslims. Mosque other thanAs a center of worship for Muslims, it is also a symbol of the greatness of the spread of Islamic da'wah (Nasikin, 2017). The mosque is the most strategic place in fostering and mobilizing the potential of Muslims to realize formidable human resources and quality ( Siswanto, 2019 ). Human resources are expected to become the driving force of da'wah and part of efforts to prosper the mosque youth. Through the role of the mosque youth, the mosque can become a forum for the formation of morality and morality education for the surrounding community, particularly teenagers who are now very vulnerable in the real world (Nevihwa, Maya,\& Yasyakur, 2018).

The change in focus from using conventional media to digital media has now penetrated various communication needs (Baran \& Davis, 2010). The needs and interests of the community, especially youth groups, in meeting the needs of understanding against the teachings of Islam is a driving force for teenagers to use social media as a platform that is easily accessible and able to provide information quickly. Digital literacy owned by the youth group is an easy way to adapt to new internet-based media (Tjahyadi, 2007).

Virtual da'wah has become an alternative in da'wah in the digital era. Utilizationsocial media for preaching virtually can then be a channel (channel). Da'wah is effective if designed creatively through interesting messages to be a preference for teenagers. Mosque youth can perform worship activities and social through social media. Youth mosques in urban areas certainly have challenges in the flow of information and entertainment that can expose urban youth social life.

The youth of the Baitissalam Mosque in the middle of the capital city of Probolinggo has the spirit of da'wah to try to prosper the mosque. Baitissalam Mosque has adequate internet connection facilities. This facility can be used for: support the formulation, production, development, and distribution process of 
da'wah messages based on digital data ( Wasesa, 2011 ). The youth of the Baitissalam Mosque have started their activities virtual da'wah through video postings on Instagram social media. Recently the content that has been created is in the form of a counter-trend of "How Geregetnya You Are" which then viral on social media by contextualizing the message in a teenage-style messagelslamic (Nuraini \& Muhtarima, 2016). This early activity has shown enthusiasm reaching virtually for mosque youth. Still, Baitissalam Mosque Youth does not yet have a strong concept to design messages persuasive virtual da'wah, so they need reinforcements. Several administrators conveyed that they create content only when an idea comes up, is not programmed, and has a systematic timeline even though they realize that what they are posting is a message laden with religious values and reminders for the younger generation of Muslims (Weiss, 2018).

Lack of mastery of concepts and strategies in the use of social media forpreaching is a separate problem for partners. Social media that has a lotused just "fad" is used but not used as a mediumvirtual da'wah whose messages are deliberately made in a systematic and structured manner so thatThere are clear and measurable goals. So that it can be formulated things that becomepartner problems are (1) virtual da'wah is only done "on a whim" isn't it? Used as da'wah activities whose messages are systematic and structured so that they can be measured its effectiveness; (2) it is not yet realized that virtual da'wah can improve mosque youth 'branding' as one of the strategic groups to spread values religious values in the millennial and contemporary era, especially for teenagers; and (3) lack of mastery concepts and strategies in the implementation of virtual da'wah carried out through creative content.

\section{Method}

Community Partnership Program activities are carried out by implementing various methods, namely education by providing socialization and theoretical strengthening by both parties resource persons from the team, and audio-visual training, creating creative content through works short film (short movie) to be posted via Instagram social media delivered by a resource person from the Production House "Rumah Kreatif Condet" (RKC). The steps taken by the team are: (1) collecting information initial by conducting initial observations, and interviews with management in the context of problem mapping; (2) Identify the problem, where the team did identify problems and agree on solutions to reinforce the form of conceptual understanding and training for ; (3) provide a solution that conveys reinforcement about the importance of social media for virtual da'wah facilities, potential map media as propaganda channels, and provide training from social 
media practitioners to improve digital literacy, especially regarding creative content via audio-visual to be posted via social media; (4) team coordination with the management and the related Baitissalam Mosque Takmir Councilpreparation and schedule of activities; (5) implementation of activities, activities carried out for 2 (two) days, namely 23 and 24 February 2019 at the Baitissalam Mosque Hall, Paiton, Probolinggo.

\section{Results and Discussion}

Community Service Activities carried out with Baitissalam Mosque Youth partners , Paiton, Probolinggo, and became the organizing committee for the event these activities by contributing to: (1) determining the place and time activity; activities carried out as part of the work program in the field of publication; (2) coordination with the Mosque Takmir Council regarding place permits; (3)mobilization of activity participants. This activity was attended by a number of 20 administrators with varying levels of education, ranging from junior high school students to university students; and (4) event managers; where event officers such as registration, MC, qori, documentation, and all consumption is done by .

The event started with the recitation of the holy Qur'an and the opening by the ChairpersonThe Takmir Council of the Baitissalam Mosque and the Chair of as hosts. EventThe next step is the reinforcement provided by the Service Team. Source person First, H. Ahmad Fawaid, M.Th.I. delivered material related to the concept ofvirtual da'wah. Virtual da'wah can be interpreted as an invitation to humans tothe path that Allah blesses by using the internet (washilah) media. Currently, reaching virtual reality has become a new approach in da'wah strategy that is very possible this is done with social media that teenagers, including teenagersBaitissalam mosque can access. In the association's perspective, the idea of virtual da'wah becomes one of the formulations of the results of the 2015 Muktamar Nahdlatul Ulama in Jombang. Da'wah virtual is da'wah bi ahsanil qawl: da'wah with oral, written, picture, and symbols in the form of internet-based audio, video, and audiovisual, as well ashas a public, mass, and social context. In virtual da'wah, anyone can beda'wah actors, not only those who are often called 'ustadz'/'ustadzah' or 'kyai' because basically in Islam, conveying goodness is the obligation of every Muslim. Maudu' (theme/topic) of virtual da'wah can certainly be related to aqidah, morals, ahkam, ukhwah, education, social, culture, society, amar makruf and nahi munkar, and other current issues, with a note that the packaging (packaging) of this themesmust be adapted to the mindset of the millennial generation and adapted to the media. 
Meanwhile, the second resource person, Farida Hariyati, deliver material about mosque youth branding through virtual da'wah. Mosque youth are sometimes considered less sociable, anti-technology, and old-fashioned. Whereas, in this millennial era, teenagers are a group that has the potential toconvey many messages of kindness through social media such as Facebook, Twitter, and Instagram. Branding is a good communication activity by companies or individuals to build and raise brands orbrands. In this context, of course, Brand does not only mean goods or products, but also individuals, so it is called Personal Branding. Personal Branding is an effort or effort made by someone to make themselves a brand known and remembered so that it has an assessment or view separate from the general public. Personal brands can reflect the "distinctive differentiator" or show someone's uniqueness. Regarding the mosque's youth, then skills in virtual preaching on social media through creative content can be a personal branding commodity to give a distinction and, in the end, improve the image of mosque youth in the millennial era (Nasrallah, 2015).

Training on creating creative content by RKC was held on Sunday, 24 February 2019, with speakers: Ihsan Kamil. Source person provides material about making short films by paying attention to the processes, from the pre-production process, the initial process, the production process, and the post-production process, as well as what is the mechanism for promoting the results of the films that the participants so has made that it gets a good response from the audience, or subscribers, or viewers.

After the presentation of the material, participants were given the task of making a short video by empowering participant resources, both as content creators, crew, and talent (Surjono, 2013). The practical activity of making this short video into a fun challenge for the trainees because they experience directly how to make a video for creative virtual da'wah guided by professionals (Astuti, 2002).

The community partnership program activities have been well implemented and get a positive response and enthusiasm from the teenagers and young people active in the youth activities of the Baitissalam Mosque, Paiton, Probolinggo. Implementing this partnership program can provide an initial stimulus for strengthening virtual da'wah in the millennial era, which is possible for teenagers. As a result of this training, the participants made works in short videos with the title "SEDEKAH" guided directly by the production house Rumah Kreatif as a practitioner resource. This video is projected to be uploaded on the account youtube as an authentic work of the Baitissalam Mosque Youth as a first step for starting a virtual da'wah movement for the millennial generation (George et al., 2013). 
The output of this Community Service activity is awareness. The virtual da'wah carried out by needs to be designed more strategically, systematic, and structured; gained awareness that virtual da'wah through social media can increase the 'branding' of mosque youth as a strategic group in spreading religious values; and the development of mastery of concepts and strategies virtual da'wah through packaging messages in creative content.

\section{Conclusion}

From the results of community service activities, several conclusions can be drawn that the series of strengthening the concept of virtual da'wah, branding, and creative content training provide increased understanding, awareness, and skills to administrators. However, there are some weaknesses that the activity should be carried out on an ongoing basis so that still gets assistance regularly intensive in doing virtual da'wah.

\section{Acknowledgement}

The community service team expresses their sincere gratitude to the Institute Community Service and Empowerment (LPPM) UNUJA, which has provided support and assistance, both material and non-material, so that activities Community Partnership Program can be implemented smoothly and provide benefits for participants. Thank you to all the management and members of Islamic Youth Baitissalam Mosque and NU Paiton Youth Branch Leader as partners who entrust the team to provide education related to virtual da'wah for teenagers.

\section{References}

Astuti, S. (2002). Tinjauan Aspek Mutu dalam Kegiatan Industri Pangan. Institut Pertanian Bogor.

Baran, S. J., \& Davis, D. K. (2010). Teori Komunikasi Massa : Dasar, Pergolakan, dan Masa Depan. Jakarta: Penerbit Salemba Humanika.

George, P., Dumenco, L., Dollase, R., Taylor, J., Wald, H., \& Reis, S. (2013). Introducing technology into medical education: Two pilot studies. Patient Education and Counseling, 293(3), 522-524. https://doi.org/https://doi. org/10.1016/j.pec.2013.04.018. 
Nasikin, M. (2017). Memakmurkan Masjid Melalui Gerakan Shalat Berjama'ah di Desa Parampuan Kecamatan Labuapi Kabupaten Lombok Barat. El-Tsaqafah: Jurnal Jurusan PBA, 16(1), 93-102.

Nevihwa, N., Maya, R., \& Yasyakur, M. (2018). Peran Perhimpunan Remaja Masjid At-Taqwa (Permat. El-Tsaqafah: Jurnal Jurusan PBA, 16(1), 93-102.

Nasrullah, R. (2015). Media Sosial Perspektif Komunikasi, Budaya, dan Sosioteknologi. Bandung: Simbiosa Rekatama Media.

Nevihwa, N., Maya, R., \& Yasyakur, M. (2018). Peran Perhimpunan Remaja Masjid At- Taqwa (Permata) Dalam Meningkatkan Akhlakul Karimah Masyarakat Kampung Ciampea Ilir Desa Tegalwaru Kecamatan Ciampea Kabupaten Bogor. Prosa PAl: Prosiding Al Hidayah Pendidikan Agama Islam, 1(1), 19-27.

Nuraini, N., \& Muhtarima, M. F. (2016). Implementasi Kurikulum 2013 Pada Mata Pelajaran Pendidikan Agama Islam di SD Muhammadiyah Terpadu Ponorogo. Jurnal Pendidikan Islam, 1, 52-80.

Restendy, M. S. (2018). Dakwah Virtual Yayasan Spirit Dakwah Indonesia (SPIDI) Tulungagung. In Proceedings of Annual Conference for Muslim Scholars (pp. 298-305).

Risdiana, A., \& Ramadhan, R. B. (2019). Dakwah Virtual sebagai Banalitas Keberagamaan di Era Disrupsi. FIKRAH, 7(1), 133-154.

Siswanto, B. (2019). Peranan Masjid Dalam Membentuk Karakter Akhlak Muslim Mahasiswa Stsn. Tadrib, 5(1), 21-33.

Supratman, L. P. (2018). Penggunaan Media Sosial oleh Digital Native.

Surjono, H. D. (2013). Peranan Teknologi Informasi dan Komunikasi (ICT) dalam Peningkatan Proses Pembelajaran yang Inovatif. Seminar Nasional Pendidikan \& Saintec UMS.

Tjahyadi, S. (2007). IImu Teknologi dan Kebudayaan. yogyakarta: Liberty Yogyakarta. Wasesa, S. A. (2011). Political Branding \& Public Relations. Jakarta: PT Gramedia.

Weiss, M. L. (2018). Media Power in Indonesia: Oligarchs, Citizens and The Digital Revolution by Ross Tapsell (Review). USA: Cornell University Press. 